\title{
Comparison of Fatty Acids Composition and Oil Quality Factors of Different Market Type Peanut (Arachis hypogaea L.) Varieties
}

\author{
Halil BAKAL ${ }^{1}$ \\ ${ }^{1}$ Cukurova University Faculty of Agriculture
}

December 1, 2020

\begin{abstract}
This study was conducted at the experimental area of the Cukurova University, Faculty of Agriculture in 2017,2018 and 2019 in Adana (Mediterranean Region)-Turkey. The objective of this study was to compare of fatty acids composition and oil quality factors of different market type peanut (Arachis hypogaea L.) varieties grown as a main crop. Four different market type peanut varieties, including Virginia (Halisbey), Runner (G.Green), Spanish (Florispan) and Valencia (G.Red) were used as plant material in this research. The experimental design was a randomized complete block design with three replications. Oil content, fatty acids composition such as oleic acid, linoleic acid, stearic acid palmitic acid and oil quality factors such as Oleic/linoleic acid ratio (O/L) and iodine value (IV) of peanut seed oil were investigated. According to a three-year results; the oil content of the peanut varieties varied between $45.38 \%$ and $51.28 \%$. The total saturated fatty acid was higher in Spanish and Valencia types than Virginia and Runner types. On the other hand, the total unsaturated fatty acid was higher in Virginia and Runner types than the others types.
\end{abstract}

\section{Introduction}

Peanut seeds contain approximately $42-56 \%$ oil, $25-35 \%$ protein and $20 \%$ carbohydrate and is a rich source of minerals (K, Ca, Mg, Fe and Z) and vitamins such as E, K and B group (Isleib et al., 2008; Hassan and Ahmed, 2012). For these reason, peanut kernel is an important and good source of oil, protein and fatty acids for human nutrition. The annual peanut production is around 42.0 million tons in the world in 2019 (Anon., 2019). 53\% of the world peanut production uses for the oil production, $32 \%$ for the peanut butter, confectionary and roasted and the remaining $15 \%$ seedcake after oil extraction is used as feed for livestock. For these reason, Peanut (Arachis hypogaea L.) is an important oilseed crop for vegetable oil production in the world. Peanut production is getting important crop by year to year. Peanut production was 173.800 ton in Turkey in 2018 (Anon., 2019) and all of them are used for the human nutrition (roasted peanut). Peanut is a legume crop and it fixes about $150 \mathrm{~kg} / \mathrm{ha}$ nitrogen to soil from the atmosphere by the Rhizobium bacteria living their roots (Arioglu, 2014).

Oil and protein content are the main nutritional quality factors in peanut seed. Nutritional quality of the seed is influenced by several factors such as environmental factors, genetic factors and their interaction (Isleib et al., 2008). Chowdhury et al. (2015) found out that the oil and protein content of peanut varieties were varied between $49.20-50.76 \%$ and 30.62-38.88\%, respectively. Raheja et al. (1987) found out that the oil content of Virginia runner market type peanut varieties was $45.50-52.10 \%$, Virginia bunch types was $47.50-51.90 \%$ and Spanish bunch types was $44.70-54.00 \%$.

The nutritional and storage qualities of peanut are determined by its fatty acids composition. The major fatty acids in peanut oil are palmitic (C16:0), stearic (C18:0), oleic (C18:1) and linoleic (C18:2) acids (Chowdhury et al., 2015). The amount of saturated (palmitic and stearic) and unsaturated (oleic and linoleic) fatty acids in peanut oil varies from 10.92 to $17.47 \%$ and from 81.13 to $94.81 \%$, respectively. Peanut oil is rich in oleic 
and linoleic acids. Oleic acid content in peanut genotypes can vary from 21 to $85 \%$ and linoleic acid from 2 to $43 \%$ (Andersen and Gorbet, 2002).

The fatty acid composition of peanut is becoming increasingly important diet for healthy living. The nutritional quality of peanut depends on the relative proportion of saturated and unsaturated fatty acids in the oil. A high proportion of polyunsaturated fatty acid is desirable because it lowers plasma cholesterol and low-density lipoprotein (LDL) content, which may reduce the risk of coronary heart disease (Mzimbiri et al., 2014).

Brown et al. (1975) and Chaiyadee et al. (2013) reported that the ratio of oleic acid to linoleic acid $(\mathrm{O} / \mathrm{L}$ ratio) and iodine value determine the quality, storability and shelf-life of peanut oil and its products. In addition, the iodine value (IV) was used to determine the degree of unsaturated fatty acid and the stability of peanut oil. High O/L ratio and low IV value generally indicate good stability and long shelf-life (Worthington et al., 1972; Braddock et al., 1995).

Golombek et al. (1995), Hinds (1995), Andersen and Gorbet (2002) Isleib et al. (2008), Shin et al. (2010), Singkham et al. (2010), Chowdhury et al. (2015), Gulluoglu et al. (2017) and Bakal and Arioglu (2019) indicated that the fatty acid composition of peanut oils varies significantly by genotype, soil nutrient, seed maturity, production year and planting date, geographic location of production, and environmental factors including temperature and other seasonal effects.

Oil content and fatty acid composition of peanut have been studied in different cultivars and different environments and it has been reported that the oil content of peanut cultivars varied between $37.9-56.3 \%$, oieic acid 37.7-82.2\%, linoleic acid 2.9-41.5\%, palmitic acid 9.6-13.2\%, stearic acid 1.6-3.7\%, arachidic acid 1.2-1.7\%, behenic acid 1.2-3.5\% and iodine value varied between 88.6 to 105.4 (Dwivedi et al., 1996; Ozcan and Seven, 2003; Onemli, 2012; Hassan and Ahmed, 2012; Chaiyadee et al., 2013; Mzimbiri et al., 2014; Chowdhury et al., 2015).

Peanut has been grown as a main and double cropped after a small grain harvest in the Cukurova region (Mediterranean Region) in Turkey. It is important to know the content of peanut fatty acids for better quality and safety of its product. Fatty acid composition of peanut is not constant. The fatty acid composition of peanut oil varies depending on growing seasons and varieties. The objective of the study was to determine oil content, fatty acids composition and oil quality factors $(\mathrm{O} / \mathrm{L}$ and $\mathrm{IV})$ of different market type peanut cultivars grown as a main crop in Adana (Mediterranean Region)-Turkey.

\section{Materials and Methods}

\section{Material}

Field experiments was conducted during 2017, 2018 and 2019 growing seasons at Experimental Farm of Agricultural Faculty, Cukurova University (Southern Turkey, $36^{\circ} 59^{\mathrm{l}} \mathrm{N}, 35^{\circ} 18^{1} \mathrm{E}$ and $23 \mathrm{~m}$ above sea level) as a main crop in Adana, Turkey. In this research, Halisbey, Georgia Green, Florispan and Georgia Red peanut varieties were used as plant material belonging to Virginia, Runner, Spanish and Valencia market types, respectively (Table 1 ).

The soil texture was clay loam. The soil tests indicated that $\mathrm{pH}$ of 7.6-7.7 with high concentrations of $\mathrm{K}_{2} \mathrm{O}$ and low concentrations of $\mathrm{P}_{2} \mathrm{O}_{5}$. In addition, the organic matter and nitrogen content of the soil were very low. The lime content was 21.1-21.8 \% in the soil of experimental area.

This study was conducted in Adana province ( Mediterranean environment) in Turkey and in this region, winters are mild and rainy, whereas summers are dry and warm, which is a typical of a Mediterranean climate. The climate data such as temperature, precipitation and relative humidity during the 2017, 2018 and 2019 growing period and long term (LT) average (1929-2019) in Adana was shown in Table 2.

The average monthly air temperature during the research period (April-September) was varied between 18.5$30.4^{\circ} \mathrm{C}$ in $2017,20.2-29.7^{\circ} \mathrm{C}$ in 2018 and it was varied between 17.0 and $29.6^{\circ} \mathrm{C}$ in 2019 . The total rainfall was $138.2 \mathrm{~mm}, 86.8$ and $105.8 \mathrm{~mm}$ during the growing period in 2017, 2018 and 2019, respectively. The 
average relative humidity was ranged from $60.7 \%$ to $69.1 \%$ in $2017,61.2 \%$ to $70.2 \%$ in 2018 and $57.6 \%$ to $68.8 \%$ in 2019. As it can be seen in Table 2, the differences between the years and long term for the climate data were not found very significant except total rain fall.

\section{Method}

The experiment was designed a randomized complete block design with three replications. The pre-sowing herbicide was applied to the soil and the plots were kept weed-free by hand weeding during the growing period. $300 \mathrm{~kg} \mathrm{ha}^{-1}$ of Di-ammonium phosphate $\left(54 \mathrm{kgha}^{-1} \mathrm{~N}, 138 \mathrm{~kg} \mathrm{ha}^{-1} \mathrm{P}_{2} \mathrm{O}_{5}\right)$ fertilizer was applied and incorporated to soil before planting. Urea $(46 \% \mathrm{~N})$ at the rates of $400 \mathrm{~kg} \mathrm{ha}^{-1}$ was applied as two times; before first (beginning of flowering) and third (pod formation) irrigation $\left(200 \mathrm{~kg} \mathrm{ha}^{-1}+200 \mathrm{~kg} \mathrm{ha}^{-1}\right)$ in each three years. Plot size was $2.8 \times 5.0 \mathrm{~m}\left(14.0 \mathrm{~m}^{2}\right)$ and spacing between row and plant was 70 and $15 \mathrm{~cm}$, respectively. The seeds were treated with fungicide before sowing $\left(80 \%\right.$ Thiram ) at the rate of $4 \mathrm{~g} \mathrm{~kg}^{-1}$ seeds for controlling Aspergillus Crown rot (Aspergillus niger van Tieghem). The seeds were sown by hand at 5 April in 2017, 7 April in 2018 and 6 April in 2019. During the growing period, recommended pesticides and fungicides were applied at proper time intervals to control insects and diseases. Sprinkler irrigation was applied at 10 days intervals to maintained soil moisture close to field capacity. The remaining cultural practices such as inter row cultivation and weed control were applied during the growing period. The plants were harvested by hand after sowing 150 days (in September) in each three years.

\section{Data collection and analysis :}

The data belonging to oil content and oil quality characteristics such as fatty acids composition, L/O and Iodine values (IV) were recorded after harvesting (Gulluoglu et al., 2016).

The oil content was extracted from peanut seeds using "Soxhlet equipment" and oil percentage was estimated according to Association of Official Analytical Chemist (AOAC, 2010). The fatty acids composition of the peanut oil was analyzed according to Association of Official Analytical Chemist (Anon., 2010) using Gas Chromatograph equipment (Hewlett-Packard Company, Wilmington, DE, USA). Iodine values (IV) $=[(\%$ oleic acid $\times 0.8601)+(\%$ linoleic acid $\times 1.7321)]$ and Oleic acid/Linoleic acid $(\mathrm{O} / \mathrm{L})$ ratio $=[\%$ oleic acid (18:1)/linoleic acid (18:2)] of the peanut oils were calculated using the equation given by Hashim et al. (1993) and Chowdhury et al. (2015).

The data were statistically and correlation analyzed by using JMP 8.1.0 package program with repeat years on randomized complete block design. The Least Significant Differences (LSD) test was used to compare the treatments at 0.01 level.

\section{RESULTS and DISCUSSIONS}

The average data (three years) belonging to oil content, fatty acids composition, $\mathrm{O} / \mathrm{L}$ ratio and iodine value of different market type peanut varieties has been presented in Table 3 and Fig 1.

\section{Oil Content}

As it can be seen in Table 3 the results indicated that the differences between the peanut varieties were statistically significant for the oil content in a three-year average. The oil content values varied between $45.38 \%$ and $51.28 \%$ in peanut varieties. The oil percentage was the highest in G.Green $(51.28 \%)$ and followed by Florispan (50.54\%), Halisbey (49.87\%) and the lowest in G.Red (45.38\%) varieties. According to a three-year average, the highest and the lowest oil percentage was obtained from Runner type (G.Green) and Valancia type (G.Red) peanut varieties, respectively. Onemli (2012), Gulluoglu et al. (2017) and Arioglu et al. (2018) reported that the oil percentage of peanut varieties varies between 35-56\% depending on genotype, seed maturity, growing season and crowing conditions. The amount of oil in peanut seed has been shown to vary with the cultivar, market type and the environment conditions under which the seed were produced (Sanders et al., 1995; Isleib et al., 2008). Many researchers reported that the oil content values of peanut varieties in different market types ranged from $42.0 \%$ to $53.8 \%$ in the Spanish type, from $45.0 \%$ to $52.6 \%$ in the Virginia type, from $41.2 \%$ to $53.6 \%$ in the Runner type and from $43.0 \%$ to $48.0 \%$ in Valencia type 
varieties (Asubio et al., 2008; Calıskan et al., 2008; Onemlı, 2012; Wang et al., 2013; Arioglu et al., 2018). Significant differences for oil content among the cultivars are attributable to the genetic makeup and place of their origin (Hassan et al., 2005). These results are in agreement with the findings of Raheja et al. (1987), Chowdhury et al. (2015) and Bakal and Arioglu (2019).

\section{Saturated Fatty Acids Composition}

The major saturated fatty acids in peanut oil are palmitic (16:0) and stearic (18:0) acids. According to a three-year result, significant differences were observed between market types for palmitic and stearic acids. Palmitic and stearic acids percentage values of the peanut varieties varied between 10.04-12.68\% and 2.32$3.36 \%$, respectively (Table 3). The palmitic and stearic acids percentage were the highest in Florispan $(12.68 \%$ and $3.36 \%)$ variety. On the other hand, the palmitic and stearic acids were the lowest in Halisbey (10.04\%) and G.Green (2.32\%) varieties, respectively (Table 3). The highest palmitic and stearic acids percentage were found from Spanish type (Florispan) and the lowest from Virginia (Halisbey) and Runner market type peanut varieties, respectively. It was determined that the total amount of saturated fatty acid was higher in Spanish and Valencia market type of peanuts than Virginia and Runner market type of peanut varieties (Table 3 ).

The saturated fatty acids content in peanut oil were strongly influenced by genotype and harvesting time (Isleib et al., 2008; Bakal and Arioglu, 2019). Fatty acid composition of peanut has been studied in different cultivars and different environments and it has been reported that the palmitic acid content of peanut cultivars varied between 8.6-14.1\% and stearic acid between 1.6-3.7\% (Onemli, 2012; Chaiyadee et al., 2013; Mzimbiri et al., 2014; Chowdhury et al., 2015; Bakal and Arioglu, 2019).

Significant differences for palmitic and stearic acids percentage among the cultivars are attributable to the genetic makeup and place of their origin (Hassan et al., 2005). These results are in agreement with the findings of Anderson and Gorbet (2002), Ozcan and Seven (2003), Hassan et al. (2005), Gulluoglu et al. (2016), Sogut et al. (2016), Arioglu et al. (2018) and Bakal and Arioglu (2019).

\section{Unsaturated Fatty Acids Composition}

The major unsaturated fatty acids in peanut oil are oleic (C18:1) and linoleic (C18:2) acids. As it can be seen in Table 3, the differences between the market types of peanut varieties for the unsaturated fatty acids (oleic and linoleic acids) values were statistically significant in a three-year average. According to a three-year average oleic and linoleic acid percentage varied between $37.46 \%$ and $51.97 \%$, respectively (Table 3 ). The highest oleic acid percentage $(51.97 \%)$ was obtained from Virginia market type peanut variety (Halisbey) and the lowest $(37.46 \%)$ from Spanish market type variety (Florispan). It was determined that the total amount of unsaturated fatty acid was higher in Virginia and Runner market type of peanut varieties than Spanish and Valencia market type of peanut varieties in this study. Bakal and Arioğlu (2019) indicated that the oleic and linoleic acids percentage varied between $39.05-60.45 \%$ and $28.18-30.05 \%$, respectively in main crop growing season. How and Young (1983), Ozcan and Seven (2003) and Wang et al., (2013) indicated that the unsaturated fatty acids such as oleic and linoleic acids composition of peanut oils varied between 35-65\% and 19-45\%, respectively. Hassan et al (2005) and Gecgel et al. (2007) reported that significant differences for unsaturated fatty acids among the peanut cultivars are attributable to the genotype. Similar results were obtained in many studies on fatty acids composition (Onemli,, 2011; Chowdhury et al., 2015; Gulluoglu et al., 2017; Arioglu et al., 2018; Asik et al., 2018; Bakal and Arioglu, 2019).

\section{Oil Quality Values (O/L and IV)}

The ratio of oleic acid to linoleic acid (O/L ratio) and iodine value (IV) determine the nutritional quality, storability and shelf-life of peanut oil and its products. A high oleic to linoleic $(\mathrm{O} / \mathrm{L})$ acid ratio $(>10: 1)$ in peanut results an increased self life (up to 10 times) and improved flavor when compared to a normal $\mathrm{O} / \mathrm{L}$ ratio $(1.5 / 1)$. In addition, the iodine value was used to determine the degree of unsaturated fatty acid and the stability of peanut oil. High $\mathrm{O} / \mathrm{L}$ ratio and low IV value generally indicate good stability and long shelf-life (; Chaiyadee et al., 2013; Chamberlin et al., 2014). 
As it can be seen in Table 3, the differences between the peanut varieties for the $\mathrm{O} / \mathrm{L}$ values were statistically significant in main crop growing season. According to a three-year average, $\mathrm{O} / \mathrm{L}$ values of the peanut varieties varied between 0.97 and 1.91. The $\mathrm{O} / \mathrm{L}$ value was 0.97 in Florispan, 1.23 in G.Red, 1.50 in G.Green and 1.91 in Halisbey peanut varieties in a three-year average. The highest $\mathrm{O} / \mathrm{L}$ ratio was obtained from Virginia market type peanut variety due to higher oleic acid and lower linoleic acid percentage compared to other market types of peanut varieties. On the other hand, the lowest $\mathrm{O} / \mathrm{L}$ ratio was obtained from Spanish market type peanut variety due to lower oleic acid and higher linoleic acid percentage. Bakal and Arioglu (2019) indicated that $\mathrm{O} / \mathrm{L}$ value in peanut oil was increased when the harvesting delayed. They also indicated that the reason of $\mathrm{O} / \mathrm{L}$ increases because the oleic acid percentage was increased and the linoleic acid was decreased when the harvesting times were delayed. Bovi (1982), Raheja et al. (1987) and Onemli (2012) reported that there was a negative correlation between oleic acid and linoleic acid. Gulluoglu et al. (2016) reported that the $\mathrm{O} / \mathrm{L}$ ratio of the peanut oil varied between 1.92 and 2.23 at different harvesting times in main crop growing season. The $\mathrm{O} / \mathrm{L}$ ratio was increase when the harvesting delayed. Oleic and Linoleic acids percentage of peanut varieties were found different. For these reasons, $\mathrm{O} / \mathrm{L}$ ratio of the peanut varieties was found different. Hassan et al. (2005) reported that significant differences for unsaturated fatty acids and $\mathrm{O} / \mathrm{L}$ ratio among peanut cultivars are attributable to the genotype.

Iodine values (IV) of the peanut oils were calculated using the $(\%$ oleic acid $\mathrm{x} 0.8601)+(\%$ linoleic acid $\mathrm{x}$ 1.7321) equation given by Chowdhury et al. (2015). IV is important quality factor in peanut oil. Chaiyadee et al. (2013) and Brown et al. (1975) reported that the ratio of oleic acid to linoleic acid (O/L ratio) and iodine value determine the quality, storability and shelf-life of peanut oil and its products. In addition, the iodine value (IV) was used to determine the degree of unsaturated fatty acid and the stability of peanut oil. High-oleic peanut has longer self-life than low-oleic peanut and it has better flavor quality or stability than low-oleic peanut. Worthington et al. (1972) and Young et al. (1972) indicated that Iodine value indicates of the stability and self life of peanut oil. Low iodine value generally indicates good stability and long shelf-life.

The differences between the peanut varieties for the iodine value were found statistically significant in a three-year average. According to a three-year average, the iodine values of the peanut varieties varied between 91.80 and 99.23 in main crop growing season (Table 3). Iodine value was the highest in Florispan (99.23) and the lowest in Halisbey (91.80) varieties. Iodine value was the highest in Spanish market type peanut varieties due to higher linoleic acid percentage compared to other market types of peanut varieties. High linoleic acid percentage increases the iodine value (\% Linoleic acid x 1.7321). Linoleic and oleic acids percentage was the important factors for indicating the iodine value. Andersen and Gorbet (2002) concluded that biochemical relationships between variables of fatty acids were more greatly affected by genetic effects than by environmental conditions. The reason for the differences between the varieties for the iodine value was them having different oleic and linoleic acids content. These results are in agreement with the findings of Andersen and Gorbet (2002), Chaiyadee et al. (2013), Chamberline et al. (2014), Chowdhury et al. (2015), Gulluoglu et al. (2016) and Arioglu et al. (2018) were indicated similar results.

\section{Conclusion}

Peanut seeds contain approximately $42-56 \%$ oil, $25-35 \%$ protein and $18-20 \%$ carbohydrate and are rich source of minerals (K, Ca, Mg, Fe and Z) and vitamins such as E, K and B group. For these reason, peanut kernel is an important and good source of oil, protein and fatty acids for human nutrition. Peanut production is getting important crop by year to year. Peanut production was 173.800 ton in Turkey in 2018 and all of them are used for the human nutrition (roasted peanut). The objective of this study was to compare of fatty acids composition and oil quality factors of different market type peanut (Arachis hypogaea L.) varieties grown as a main crop in Cukurova region (Mediterranean Region)-Turkey.

According to a three-year results; the oil content of the peanut varieties varied between $45.38 \%$ and $51.28 \%$. The total saturated fatty acid was higher in Spanish and Valencia types than Virginia and Runner types. On the other hand, the total unsaturated fatty acid was higher in Virginia and Runner types than the others types. 
The ratio of oleic acid to linoleic acid (O/L ratio) and iodine value (IV) determine the nutritional quality, storability and shelf-life of peanut oil and its products. In addition, the iodine value was used to determine the degree of unsaturated fatty acid and the stability of peanut oil. High $\mathrm{O} / \mathrm{L}$ ratio and low IV value generally indicate good stability and long shelf-life. According to a three-year average, the highest $\mathrm{O} / \mathrm{L}$ and IV was obtained from Virginia type (Halisbey) and Spanish (Florispan) market type peanut varieties, respectively. Halisbey peanut variety has the highest oil quality due to high $\mathrm{O} / \mathrm{L}$ and Low IV among the tested peanut varieties.

\section{LITERATURE CITED}

Abouziena, H. F. H., Sharma, S. D., \& Singh, M. (2009). Impact of adjuvants on bentazon efficacy on selected broadleaf weeds. Crop Protection, 28(12), 1081-1085.

Andersen, P. C., \& Gorbet, D. W. (2002). Influence of year and planting date on fatty acid chemistry of high oleic acid and normal peanut genotypes. Journal of Agricultural and Food Chemistry, 50(5), 1298-1305.

Anon., AOCS (2010) Official methods \& recommended practices of the American Oil Chemists Society, 4th edn. Champaign, IL Official Method.

Anon., FAO. (2019). Fao Statistical Databases. http://www.fao.org internet page.

Arioglu, H., (2014). The oil seed crops growing and breeding. The publication of University of Cukurova, Faculty of Agriculture No:A-70, 204 p. Adana-Turkey.

Arioglu, H., Bakal, H., Gulluoglu, L., Onat, B., \& Kurt, C., (2018). The effect of harvesting dates on some agronomic and quality characteristics of peanut (Arachis hypogaea L.) varieties grown as a main crop in Mediterranean region (Turkey). Turkish Journal of Field Crops , 23(1) , 27-37.

Asibuo, J. Y., Akromah, R., Safo-Kantanka, O., Adu-Dapaah, H. K., Ohemeng-Dapaah, S., \& Agyeman, A. (2008). Chemical composition of groundnut, Arachis hypogaea (L) landraces. African Journal of Biotechnology , 7(13) , 2203-2208.

Asik, F. F., Yildiz, R., \& Arioglu, H. (2018). The determination of new peanut varieties for osmaniye region and their important agronomic and quality characteristics. KSU Journal of Agriculture and Nature,21(6), 825-836.

Bakal, H., \& Arioglu, H. (2019). The determination of fatty acids composition and oil quality factors of some peanut varieties having different market types at different harvesting times in main and double crop growing seasons in Mediterranean region. Turkish Journal Of Field Crops , 24(2) , 221-229.

Bovi, M. L. A. (1982). Genotypic and environmental effects on fatty acid composition, iodine value and oil content of peanut (Arachis hypogaea L.). Ph.D. dissertation. University of Florida, p 119.

Braddock, J. C., Sims, C. A., \& O'keefe, S. F. (1995). Flavor and oxidative stability of roasted high oleic acid peanuts. Journal of Food Science, 60(3) , 489-493.

Brown, D. F., Cater, C. M., Mattil, K. F., \& Darroch, J. O. (1975). Effect of variety, growing location and their interaction on the fatty acid composition of peanuts. Journal of Food Science, 40(5) , 1055-1060.

Caliskan, S., Caliskan, M. E., Erturk, E., Arslan, M., \& Arioglu, H. (2008). Growth and development of Virginia type groundnut cultivars under Mediterranean conditions. Acta Agriculturae Scandinavica Section B-Soil and Plant Science, 58(2), 105-113.

Chaiyadee, S., Jogloy, S., P Songsri, P., Singkham, N., Vorasoot, N., Sawatsitang, P., .. \& Patanothai, A. (2013). Soil moisture affects fatty acids and oil quality parameters in peanut. International Journal of Plant Production, 7(1), 81-96.

Chamberlin, K. D., Barkley, N. A., \& Tillman, B. L. (2014). A comparison of methods used to determine the oleic/linoleic acid ratio in cultivated peanut (Arachis hypogaea L.). Agricultural Sciences , 5(3) , 227-237. 
Chowdhury, F. N., Hossain, D., Hosen, M., \& Rahman, S. (2015). Comparative study on chemical composition of five varieties of groundnut (Arachis hypogaea ). World J. of Agricultural Science, 11(5), 247-254.

Dwivedi, S. L., Nigam, S. N., Rao, R. N., Singh, U., \& Rao, K. V. S. (1996). Effect of drought on oil, fatty acids and protein contents of groundnut (Arachis hypogaea L.) seeds. Field Crops Research, 48(2-3) , 125-133.

Gecgel, U., Demirci, M., Esendal, E., \& Tasan, M. (2007). Fatty acid composition of the oil from developing seeds of different varieties of safflower (Carthamus tinctorius L.). Journal of the American Oil Chemists' Society, 84(1), 47-54.

Golombek, S. D., Sridhar, R., \& Singh, U. (1995). Effect of soil temperature on the seed composition of three Spanish cultivars of groundnut (Arachis hypogaea L.). Journal of Agricultural and Food Chemistry, 43(8) , 2067-2070.

Gulluoglu, L., Bakal, H., Onat, B., Kurt, C., \& Arioglu, H. (2016). The effect of harvesting date on some agronomic and quality characteristics of peanut grown in the Mediterranean region of Turkey. Turkish Journal of Field Crops , 21(2), 224-232.

Gulluoglu, L., Bakal, H., Onat, B., Kurt, C., \& Arioglu, H. (2017). Comparison of agronomic and quality characteristics of some peanut (Arachis hypogaea L.) varieties grown as main and double crop in Mediterranean region. Turkish Journal of Field Crops , 22(2), 166-177.

Hashim, I. B., Koehler, P. E., Eitenmiller, R. R., \& Kvien, C. K. (1993). Fatty acid composition and tocopherol content of drought stressed Florunner peanuts. Peanut Science , 20(1) , 21-24.

Hassan, F., \& Ahmed, M. (2012). Oil and fatty acid composition of peanut cultivars grown in Pakistan. Pakistan Journal of Botany , 44(2), 627-630.

Hassan, F., Manaf, A., \& Ejaz, M. (2005). Determinants of oil and fatty acid accumulation in peanut. International Journal of Agriculture and Biology , 7(6) , 895-899.

Hinds, M. J. (1995). Fatty acid composition of Caribbean-grown peanuts (Arachis hypogaea L.) at three maturity stages. Food Chemistry, 53(1) , 7-14.

How, J. S., \& Young, C. T. (1983). Comparison of fatty acid content of imported peanuts. Journal of the American Oil Chemists' Society, 60(5), 945-947.

Isleib, T. G., Tillman, B. L., Pattee, H. E., Sanders, T. H., Hendrix, K. W., \& Dean, L. O. (2008). Genotypeby-environment interactions for seed composition traits of breeding lines in the uniform peanut performance test. Peanut Science, 35(2), 130-138.

Mzimbiri, R., Shi, A. M., Liu, H., \& Wang, Q. (2014). A Review: peanut fatty acids determination using hyper spectroscopy imagine and its significance on food quality and safety. Food Science and Quality Management, 28 , 90-97.

Onemli, F. (2012). Impact of climate change on oil fatty acid composition of peanut (Arachis hypogaea L.) in three market classes. Chilean Journal of Agricultural Research, 72(4) , 483.

Ozcan, M., \& Seven, S. (2003). Physical and chemical analysis and fatty acıd composition of peanut, peanut oll and peanut butter from ÇOM and NC-7 cultıvars. Grasas y Aceites , 54(1) , 12-18.

Raheja, R. K., Batta, S. K., Ahuja, K. L., Labana, K. S., \& Singh, M. (1987). Comparison of oil content and fatty acid composition of peanut genotypes differing in growth habit. Plant Foods for Human Nutrition , 37(2) , 103-108.

Sanders, T.H., Pate, H. A., Vercellotti, J. R., \& Bett, K.I. (1995). Advances in peanut flover quality. P.528553. In H.E. Patte and H.T. stalker (Eds). Advances in Peanut Science . Amer. Peanut Res. Education Soc. Inc. Stillwarer, Oklahama. 
Shin, E. C., Pegg, R. B., Phillips, R. D., \& Eitenmiller, R. R. (2010). Commercial Runner peanut cultivars in the USA: Fatty acid composition. European Journal of Lipid Science and Technology, 112(2), 195-207.

Singkham, N., Jogloy, S., Kesmala, T., Swatsitang, P., Jaisil, P., \& Puppala, N. (2010). Genotypic variability and genotype by environment interactions in oil and fatty acids in high, intermediate, and low oleic acid peanut genotypes. Journal of Agricultural and Food Chemistry , 58(10) , 6257-6263.

Sogut, T., Ozturk, F., \& Kizil, S. (2016). Effect of sowing time on peanut (Arachis hypogaea L.) cultivars: II. Fatty acid composition. Agriculture and Agricultural Science Procedia, 10 , 76-82.

Wang, Z., Xu, Z. H., Zheng, H., Zong, H. Y., \& L1, L. (2013). Effect of peanut hull biochar on amelioration of typical orchard acidic soil in northern China. Periodical of Ocean University of China , 43(8), 86-91.

Worthington, R. E., Hammons, R. O., \& Allison, J. R. (1972). Varietal differences and seasonal effects on fatty acid composition and stability of oil from 82 peanut genotypes. Journal of Agricultural and Food Chemistry, 20(3), 729-730.

Young, C. T., Worthington, R. E., Hammons, R. O., Matlock, R. S., Waller, G. R., \& Morrison, R. D. (1974). Fatty acid composition of Spanish peanut oils as influenced by planting location, soil moisture conditions, variety, and season. Journal of the American Oil Chemists Society, 51(7) , 312-315.

\section{Hosted file}

table.pdf available at https://authorea.com/users/380521/articles/496452-comparison-offatty-acids-composition-and-oil-quality-factors-of-different-market-type-peanut-arachishypogaea-l-varieties

\section{Hosted file}

figure.pdf available at https://authorea.com/users/380521/articles/496452-comparison-offatty-acids-composition-and-oil-quality-factors-of-different-market-type-peanut-arachishypogaea-1-varieties 